\section{The Use of Plickers for Formative Assessment of Vocabulary Mastery}

\author{
1 Maya Masita \\ 2 Nur Fitri \\ 1 Universitas Muhammadiyah Bulukumba, Indonesia \\ 2 Universitas Negeri Makassar, Indonesia
}

\begin{abstract} participation.

\section{Keywords}

educational technology

Plickers application

formative assessment
\end{abstract}

The use of technology considered has able to help the learning process, especially in teaching English. In the industry revolution 4.0, there are some alternatives to teach English effectively.

Plickers is an application that can help the teachers to measure student capability. This application used printable paper clickers to assign each student using the Plickers card. The teacher is instantly checking the student responses and assessment data for every question. This study was using mixed methods design to describe the use of Plickers for formative assessment of vocabulary mastery. The finding shows that Plickers help the teacher in preparing, executing, and examining in formative assessment. This application was able to improve students' motivation and

\section{Ethical Lingua}

Vol. 7, No. 2, 2020

ISSN 2355-3448 (Print)

ISSN 2540-9190 (Online)

Corresponding Email

Maya Masita

mayamasitahir@gmail.com

Article's History

Submitted 27 May 2020

Revised 18 August 2020

Revised 18 September 2020

Accepted 25 September 2020

DOI

10.30605/25409190.179

Copyright @ 2020

The Author(s)

This article is licensed under CC BY-NC-SA 4.0 License

\section{(cc) EY-NC-SA}




\section{The Use of Plickers for Formative Assessment of Vocabulary Mastery}

Today, technologies like handphones, the internet connection, smartTV, and computer are part of daily life. However, technology provides a global infrastructure for students to learn English. The students have changed radically. The teacher-dominated or teacher-fronted classroom where the teacher talks and leads activities named teacher-centered has been replaced by the student-centered learning environment, which has contributed to the success of individual learners in language classrooms. In the student-centered classroom, students no longer desire to be passive knowledge takers, but active participants with specific concerns about their language learning needs. Their brain processes the information differently than what educators expected or designed to teach. Therefore, the teachers will find difficulties in finding and developing effective ways to engage and educate Digital Natives (GonzalezAcevedo, 2016).

Some applications can help teachers measure student ability, for example, the Plickers application. Plickers is an educational tool that uses printables, such as a quick response code. The answer options A, B, C, and D printed on the paper surrounding the image. During the learning process, the teacher shows the questions. Students show the Plickers card and show their answers. Teachers scan all response cards simultaneously using the Plickers app installed on a mobile device. They can instantly see student responses and grading data for that question, including who got the right answer and who did not. This study described the use of Plickers for the formative assessment of vocabulary mastery. The data was collected by conducting observation and interviews for teachers and students, and by collecting test results from the students' examination in the English education program, Universitas Muhammadiyah Bulukumba. This study was analyzed with reflective analysis. Using an application such as Plickers keeps the teacher and students informed of developments in learning methods.

In this era, using technology as an educational tool will help both teachers and students to achieve the learning goals. In the recent education, some teachers have paid attention to the use of smartphones or digital devices in the classroom. The usefulness of educational technology has been an interesting issue for researchers and educators. Several instructors share course materials and teaching ideas globally, thereby expanding learning opportunities and resources (Bonk, 2009). According to Sejdiu (2014), a combination of face-to-face, offline, and online learning is more effective than face-to-face learning, supported by differences in student performance. He claimed the experimental group performed better.

There are many previous studies of using technology in Education (e.g. Bonk, 2009; Pardede, 2012; Alhamami, 2013; Sejdiu, 2014; Martins et al. 2015; Pop, 2015; Buckingham \& Alpaslan, 2017; Mccargo, 2017; Şlmşek et al. 2017; Elmahdi et al., 2018; McCutcheon et al., 2018; Tompkins, Howell, \& Mull, 2018; Awaliyah et al., 2019; Beegum, 2019; Gurisik \& Demirkan, 2019; Kent, 2019; Michael et al., 2019; Sasmiko et al., 2019; and Masita, 2020). The previous study showed that using technology in education bring a positive impact on both teachers and students.

According to Awaliyah et al. (2019), the students are more relaxed in doing the exercises using educational technology proven by the results of sheet/note diary. This study aimed to 
find out the students' preference for the types of hybrid English vocabulary learning programs, online driver models, and the students' vocabulary practices by using a mixed-method design. An \& Lee (2016) have been analyzed a study on integrating the digital application into foreign language education. Their findings showed the students could engage in active language learning and experience learning while studying a foreign language with digital application. This study provides an overview of the use of digital application through an online questionnaire and a focus-group interview.

Mccargo (2017) assessed the usefulness of technology-based answer cards in improving the academic behavior of students in high school grades. This study suggests that the use of Plickers improves academic classroom behavior and reduces student destructive behavior in all three grades. One alternative educational tool that can be used is the Plickers application. Kent (2019) explain Plickers as a paper clickers that use Quick Response (QR) codes are printed on paper to be used as paper clicking tools (see Figure 1). Each aspect of the $Q R$ code corresponds to one of four directions for the card $(A, B, C$, or $D)$, with each card is assigned a unique number and is available for purchase or can be printed for free from the website.

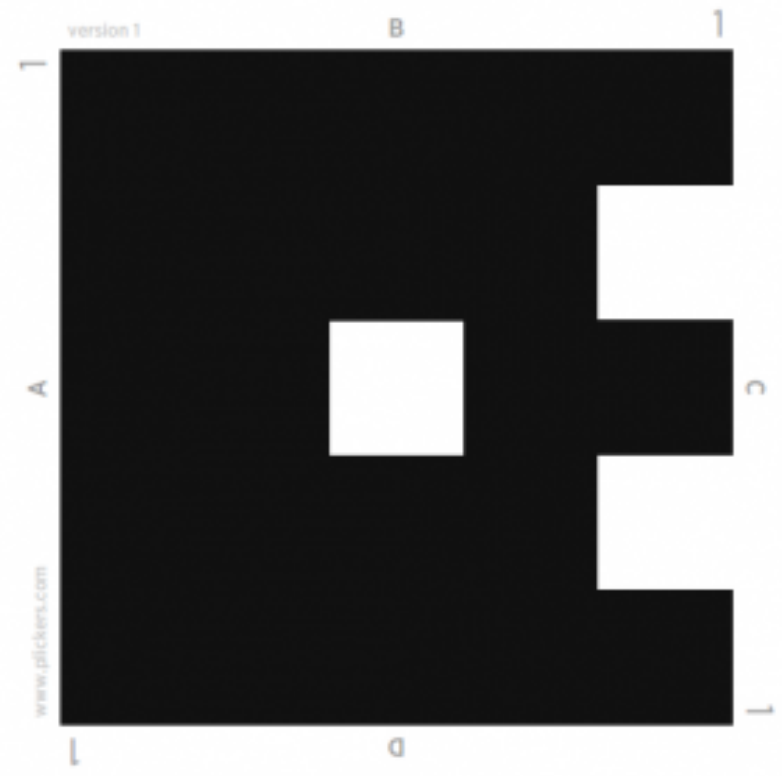

Figure 1. Plickers Card

According to Beegum (2019), Plickers is a web-based tool used for formative assessment, even in low-tech classrooms. This app requires one computer and one smartphone with the Plickers mobile app. This application is easy to use and saves time. Card numbers are assigned based on student orders. Classes can be edited, archived, or deleted. Questions can be text, images, or a combination of both. Beegum (2019) explain that Plickers is a simple and interesting application with a quick response and user-friendly interface, suitable for all ages. All student responses to using Plickers are available on the website. It can be printed or exported for evaluation and archiving.

Damick (2015) states that Plickers can be used for a variety of purposes to assess students, such as warm-up or weekend tickets formally. By observing the percentage of scores and behavior of each student to a question, the teacher uses the Live View Card to display responses from the teacher's digital device on the whiteboard. Kilickaya (2018) claims that Plickers is used to present information about the teaching and learning process using formative assessment is a strength of the application. Formative assessment is useful for 
students and teachers as it identifies gaps and identifies areas to focus on. Feedback from parallel formative assessments via the Internet is essential; This can lead to further discussion. Make more questions to better understand the content (Gurisik \& Demirkan, 2019).

Elmahdi et al. (2018) revealed that students believe the use of Plickers supported the importance of formative assessment and receiving feedback immediately. Using this app increases student engagement, saves time, provides equal opportunity for participation, and creates a fun and engaging learning environment. Kent (2019) explains the benefit of Plickers in formative assessment. This application can be adapted to various types of formative assessment, class assessment, and assessment activities. This helps students understand easily and quickly while providing the trainer with an overview of student understanding so they can identify student needs and knowledge gaps that can be addressed in subsequent lessons. Gurisik \& Demirkan (2019) analyzed the opinion of high school students about Plickers. From the research, it seems that the Plickers are making a positive contribution to learning. Students enjoy using Plickers in their lessons. Michael et al. (2019) shows that the teacher agreed, the Plickers helped them assess the reading comprehension of students in grades 3 and 4. Masita (2020) concluded that using the Plickers app can attract the attention of students so that they can focus on learning. This is due to their attractive appearance, and they have never done before.

Teaching, learning, and assessment are interrelated and integral components of the teaching and learning process (Pratolo, 2014). Brown (2003) defined assessment as an ongoing process that has a much broader scope. Assessment can take the form of notes, comments, questions, confirmations, corrections, tests, and quizzes. This assessment may include listening, speaking, reading, and writing. In learning a language, an assessment was used to collect the information and making judgments about learner's knowledge and ability to use the language. There are two kinds of assessments. They are formative assessment and summative assessment, whereas a formative assessment was used in this study.

Center (2016) explains that formative assessment aims to monitor students' learning to provide ongoing feedback that teachers can use to improve teaching and student learning. The formative assessment asks students to map a concept in the classroom to show their understanding of a topic, publish a sentence or two to define the main points of the lesson, and provide a research proposal for initial feedback. Formative assessment is a planned process in which the teacher performs a test of the student's condition, which the assessment motivates to conform to ongoing classroom procedures. With this type of assessment, teachers have the opportunity to assess the effectiveness of their teaching and to adapt and adapt their teaching activities (Popham, 1999).

This study aims to describe the use of Plickers for formative assessment of vocabulary mastery. To achieve the goal, the answers to the following questions were considered as an online formation assessment tool;

1. What is the advantage of using Plickers in formative assessment?

2. What is the disadvantage of using Plickers in language assessment?

3. What are the obstacles encountered when using Plickers in formative assessment?

4. How to solve the obstacles encountered when using Plickers in formative assessment? 


\section{Method}

The research design used is a mixed-methods to explore the use of Plickers for formative assessment of vocabulary mastery by using exploratory sequential design. Qualitative and quantitative data collected from observation, interviews, and test results.

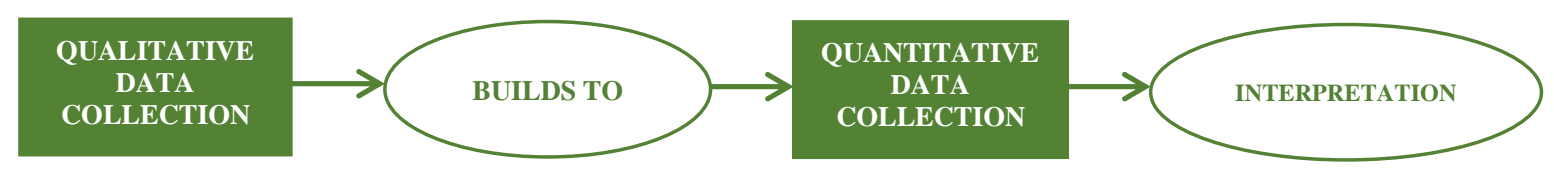

Figure 1. Exploratory Sequential Design (Creswell, 2011)

The plan starts with qualitative data and then collects quantitative information. The purpose of developing mixed sequential research methods is first to collect qualitative data to study the phenomenon and then collect quantitative data to explain the relationships in the qualitative data (Creswell, 2011). First, this study conducted a qualitative study of teacher's and students' responses about the use of Plickers for formative assessment by using observation and interview. Second, this study conducted a quantitative study of students' test results.

According to Creswell (2011), observation is the data collection method that the researcher investigates the object of the study directly. This study was using direct observation in the classroom to focus on the implementation of Plickers application for formative assessment in higher education. This study was using a semi-structured interview to measure the participants' opinions, statements, and views, even to gain the participants' experiences.

The observation was undertaken before, during, and after the assessment, and the interview after the assessment. The assessment conducted at the eighth meetings as a midterm exam and the sixteenth meetings as a final exam. This process lasted for four months. Both meetings showed that the teacher and students were understood how to apply the application. The teacher and the students were interviewed after completed the assessment. The results test were collecting from the middle exam and final exam. The test results were tabulated and reported by using descriptive statistics. The participants of this study are one English teacher and twenty-nine students. They come from the same major, English Education Program, Universitas Muhammadiyah Bulukumba.

\section{Results}

\section{Qualitative}

Based on the observation results, the use Plickers facilitate the teacher to prepare the assessment, and the application was not taking a long time. The students were relaxed and focused during the assessment. All of the participants check the progress of students in vocabulary mastery. They were checking the answer together after the assessment by having a discussion.

In the interview, the teacher said that Plickers is easy to use, and she will use it in her next classroom. The respondents will continue to use Plickers to assess students' understanding. The students claimed that using Plickers in formative assessment is like a competition in a game. All of the participants also preferred to use Plickers instead of paper tests. Meanwhile, 
all of the participants were not familiar with this application. All the participants said that this application is fun and useful. This application also shows results instantly and receive positive responses from all the participants.

\section{Quantitative}

Quantitative findings of the use of Plickers for formative assessment of vocabulary mastery in higher education are given in Table 1 as a middle-exam and final-exam.

Table 1. Middle Exam and Final Exam

\begin{tabular}{llll}
\hline No. & Students' Code & Middle & Final \\
\hline 1. & St. 1 & 80 & 100 \\
2. & St. 2 & 80 & 100 \\
3. & St. 3 & 80 & 100 \\
4. & St. 4 & 60 & 80 \\
5. & St. 5 & 60 & 100 \\
6. & St. 6 & 60 & 100 \\
7. & St. 7 & 60 & 100 \\
8. & St. 8 & 80 & 100 \\
9. & St. 9 & 60 & 80 \\
10. & St. 10 & 40 & 60 \\
11. & St. 11 & 100 & 100 \\
12. & St. 12 & 40 & 80 \\
13. & St. 13 & 40 & 60 \\
14. & St. 14 & 80 & 100 \\
15. & St. 15 & 80 & 100 \\
16. & St. 16 & 80 & 100 \\
17. & St. 17 & 60 & 100 \\
18. & St. 18 & 60 & 100 \\
19. & St. 19 & 60 & 100 \\
20. & St. 20 & 40 & 100 \\
21. & St. 21 & 40 & 80 \\
22. & St. 22 & 80 & 100 \\
23. & St. 23 & 80 & 100 \\
24. & St. 24 & 60 & 100 \\
25. & St. 25 & 60 & 100 \\
26. & St. 26 & 80 & 100 \\
27. & St. 27 & 100 & 100 \\
28. & St. 28 & 40 & 100 \\
29. & St. 29 & 80 & 80 \\
\hline
\end{tabular}


As seen in Table 1,7\% of the students get $100,38 \%$ of the students get $80,34 \%$ of the students get 60 , and $21 \%$ of the students get 40 in their middle-exam. In the final-exam, $76 \%$ of the students get $100,17 \%$ of the students get 80 , and $7 \%$ of the students get 60 .

\section{Discussion}

\section{Qualitative}

Based on the observation results, the use Plickers facilitate the teacher to prepare the assessment, and the application was not taking a long time. The teacher can easily plan corrective teaching and help these students develop action strategies based on their needs. (Beegum, 2019). Michael et al. (2019) claim it is easier to use Plickers to assess reading comprehension instead of a conventional way for assessment. Kent (2019) revealed that Plickers questions are introduced one after the other, but they can be reused and adapted.

The students were relaxed and focused during the assessment. Gurisik \& Demirkan (2019) explained that $90 \%$ of high school students commented that the lesson was more fun with the Plickers. Elmahdi et al. (2018) mention that students feel comfortable giving honest answers when teachers use Plickers. Plickers also help graphically display student responses. Gurisik \& Demirkan (2019) found that $90 \%$ of high school students said the class with the Plickers was more fun. $92 \%$ of high school students notice that Plickers shows the test result right away. All of the participants check the progress of students in vocabulary mastery. They were checking the answer together after the assessment by having a discussion. Michael et al. (2019) analyze that Plickers help the teacher to review and inform the progress of the individual learning in reading comprehension.

In the interview, the teacher said that Plickers is easy to use, and she will use it in her next classroom as she said:

"I find it easy to use Plickers in the classroom, and I will use it for the next classroom." (Teacher)

Michael et al. (2019) had also interviewed about the use of Plickers for language assessment. All the respondents agreed that it is easy to use Plickers application. The respondents agreed that the use of Plickers in assessing reading comprehension shows a positive impact (Michael et al., 2019). While in this study, the respondents will continue to use Plickers to assess students' understanding. The students claimed that using Plickers in formative assessment is like a competition in a game.

"Doing the exam is like playing a game, and I want to be a winner." (Student)

Masita (2020) concluded that varied-teaching methods make students comfort, particularly when learning is presented as interested as playing games. All of the participants also preferred to use Plickers instead of paper tests.

"Traditional methods were boring, tiring, and time-consuming." (All of the participants)

This statement is in line with Gurisik \& Demirkan (2019); 78\% of high school students preferred to use Plickers instead of the conventional method. Sasmiko et al. (2019) explained Plickers have proven to be more effective than traditional methods of improving reading comprehension and student motivation. 
All of the participants were not familiar with this application. Masita (2020) explained that this might happen if the participants are not familiar with technology in language learning.

"I never heard this application before." (All of the participants)

All the participants said that this application is fun and useful. This application also shows results instantly and receive positive responses from all the participants.

"It is different, fun, and useful. It shows results instantly." (All of the participants)

\section{Quantitative}

As seen in Table 1, $6.9 \%$ of the students get $100,38 \%$ of the students get $80,34 \%$ of the students get 60 , and $21 \%$ of the students get 40 in their middle-exam. This exam was their first time using Plickers in the assessment; all of them are not familiar with this application, and some of the students still confused about choosing the answers by rotating the QR code.

In the final-exam, $76 \%$ of the students get $100,17 \%$ of the students get 80 , and $6.9 \%$ of the students get 60 . In this exam, the students were more relaxed, being aware of choosing the answer, and they show more confidence than the previous exam. Gurisik \& Demirkan (2019) has been interview high school students about their views on using Plickers as a formative assessment tool. The students said the shots were easy, fun, and relaxing. Gives immediate results and helps to correct mistakes. They are ready to answer other questions and reinforce forgotten topics. Stickers increase student engagement and confidence. Michael et al. (2019) have been analyzing the use of Plickers to evaluate the reading comprehension. The result showed that the students felt happy to use Plickers in their classroom. They were interested in using Plickers in their future classroom. The respondents also claim that it is easy to use Plickers. The implementation of this application can be used both online and offline, so the teachers from rural areas able to use this application even though they do not have an internet connection.

Based on the description, there are several advantages of using Plickers in formative assessment. Plickers application facilitates the teacher to prepare the assessment. This application is not time-consuming. It is easy to use. The students were focused and relaxed with this activity. The use of Plickers in formative assessment showed positive responses from both teacher and students. This study also found some disadvantages of using Plickers. This application was using an internet connection, smartphone, laptop, and projector. If the teacher wants to use it offline, they have to prepare by installing the application into their smartphone. In the exam, the internet connection needed to operate the application using a smartphone, laptop, and projector at the same time. So, this application can be used if all devices are completed. This application also was not free. This application limited only for five questions if the teacher wants to use it free. To maximize the application, the teacher needs to upgrade it by paying $\$ 8.99 /$ month or $\$ 5.99 /$ year.

Based on the data, there are obstacles encountered when using Plickers in formative assessment. For the first time using Plickers in the classroom, all of the participants were not familiar with this application. To solve this problem, they are given an explanation and examples, then carried out simulations. After that, they were enthusiastic about using it. In the midterm exam, it was a blackout, so the teacher gave another activity to the students. 


\section{Conclusion}

This study concludes that Plickers help the teacher in preparing, executing, and examining in formative assessment. The teacher was interested in using this application in the other classroom. This application was able to increase students' motivation and participation. The students were focused and relaxed during the assessment. The use of Plickers application is pedagogically adaptable to a learning process, particularly in formative assessment. This study also shows positive responses from all the participants.

It is recommended that future study would be able to implement this study with different skills, fields, and levels in a longer period of time. This study should be able to use by other teachers and researchers as guidance to use interactive ways in assessing other skills, particularly in the English language.

\section{Acknowledgment}

The researcher would like to thank all of the participants in this study and the special gratitude goes to the DIRJENRISBANG, KEMENRISTEK for their funding support. I would also like to extend my appreciation to Universitas Muhammadiyah Bulukumba and LPPM for providing me with all the facility that was required.

\section{References}

Alhamami, M. (2013). Observation of YouTube language learning videos. Teaching English with Technology, 13(3), 3-17.

An, J.-W., \& Lee, S.-C. (2016). A Study on Integrating Digital Application into Foreign Language Education. 12(1), 54-59.

Awaliyah, S., Nur, A., \& Noni, N. (2019). Hybrid English Vocabulary Learning for Young Learners. Semantic Scholar. Retrieved from https://www.semanticscholar.org/paper/HYBRID-ENGLISH-VOCABULARY-LEARNINGFOR-YOUNG-Nur/8e19afc2edf7139250ab05aac6ecbec9d279fa41

Beegum, S. (2019). Plickers: A Tool for Language Assessment in the Digital Age. (October). https://doi.org/10.35940/ijrte.B1031.0782S319

Bonk, C. J. (2009). The world is open: How web technology is revolutionizing education. Association for the Advancement of Computing in Education (AACE).

Brown, H. D. (2003). Language Assessment Principles \& Classroom Practices. Longman.

Buckingham, L., \& Alpaslan, R. S. (2017). Promoting speaking proficiency and willingness to communicate in Turkish young learners of English through asynchronous computermediated practice. System, 65, 25-37. https://doi.org/10.1016/j.system.2016.12.016

Center, E. (2016). What is the difference between formative and summative assessment. Accesible at Https:/Www. Cmu. Edu/Teaching/Assessment/Basics/FormativeSummative. Html [Last Access: July 2019].

Creswell, J. W. (2011). Educational Research (4th ed.). Boston: Pearson.

Damick, J. M. (2015). Implementing Technology in an Algebra Classroom. Retrieved from https://digitalcommons.brockport.edu/cgi/viewcontent.cgi?article $=1629 \&$ context=ehd_t heses

Elmahdi, I. Al-Hattami, A., \& Fawzi, H. (2018). Using Technology for Formative Assessment to Improve Students' Learning. TOJET: The Turkish Online Journal of Educational Technology, 17(2), 182-188. 
Gurisik, A. \& Demirkan, Ö. (2019). Opinions of High School Students About Plickers: One Of The Online Formative Assessment Tools. International Journal of Scientific Research and Innovative Technology, 6(1), 11-25.

Kent, D. (2019). Plickers and The Pedagogical Practicality of Fast Formative Assessment. Teaching English with Technology, 19(3), 90-104.

Kilickaya. (2018). A Note on the 2018 Annual Conference. pp. 1-18. Retrieved from https://www.aatseel.org/100111/pdf/december_2017_aatseel_newsletter.pdf

Martins, P., Rodrigues, H., Rocha, T., Francisco, M., \& Morgado, L. (2015). Accessible Options for Deaf People in e-Learning Platforms: Technology Solutions for Sign Language Translation. Procedia Computer Science, 67, 263-272. https://doi.org/10.1016/j.procs.2015.09.270

Masita, M. (2020). Teaching Vocabulary Using Blended Learning Method Teaching Vocabulary Using Blended Learning Method. Ethical Lingua, 7(1), 128-135. https://doi.org/10.30605/25409190.143

Mccargo, M. G. (2017). The Effects of Plickers As Response Cards on Academic Engagement Behavior In High School Students.

McCutcheon, K., O'Halloran, P., \& Lohan, M. (2018). Online learning versus blended learning of clinical supervisee skills with pre-registration nursing students: A randomised controlled trial. International Journal of Nursing Studies, 82, 30-39. https://doi.org/10.1016/j.jjnurstu.2018.02.005

Michael, E. A., Ejeng, I. E. A., Udit, M. A., \& Yunus, M. M. (2019). The Use of Plickers for Language Assessment of Reading Comprehension. International Journal of Academic Research in Business and Social Sciences, 9(1). https://doi.org/10.6007/IJARBSS/v9i $1 / 5464$

Pardede, P. (2012). Blended Learning for ELT. JET (Journal of English Teaching), 2(3), 165. https://doi.org/10.33541/jet.v2i3.54

Pop, M.-C. (2015). Course Material Design Using the New Technologies in Language for Specific Purposes Teaching and Learning. Procedia - Social and Behavioral Sciences, 182, 325-330. https://doi.org/10.1016/j.sbspro.2015.04.774

Popham, W. J. (1999). Classroom assessment: What teachers need to know. ERIC.

Pratolo, B. W. (2014). EXPLORING INDONESIAN LEARNERS'BELIEFS ABOUT LANGUAGE LEARNING STRATEGIES THROUGH REFLECTION (Doctoral dissertation, Faculty of Education, Monash University).

Sasmiko, A. R., Noni, N., \& Salija, K. (2019). The Use of Plickers to Enhance Students' English Reading Comprehension at SMP Muhammadiyah 6 Makassar. Retrieved from https://eprints.unm.ac.id/15073/

Sejdiu, S. (2014). English language teaching and assessment in blended learning. Journal of Teaching and Learning with Technology, 3(2), 67-82.

https://doi.org/10.14434/jotlt.v3n2.5043

Şìmşek, Ö., Bars, M., \& Zengìn, Y. (2017). Matematik Öğretiminin Ölçme ve Değerlendirme Sürecinde Bilgi ve IIletişim Teknolojilerinin Kullanımı The Use of Information and Communication Technologies in the Assessment and Evaluation Process in Mathematics Instruction. 189-207.

Tompkins, C., Howell, N., \& Mull, C. (2018). Plickers for Success: A Technological Tool for Advancement in Data Collection. Journal of Extension, 56(7). https://www.joe.org/joe/2018december/tt5.php 